\title{
The Effect of \\ Synthetic Detergent on the Determination of the Molecular Weight of a Carotenoid-glycoprotein from Sarcina flava
}

\author{
By D. THIRKELL, M. I. S. HUNTER, J. CRAWFORD \\ AND A. S. FRACASSINI \\ Department of Biochemistry, Bute Medical Buildings, St Andrews, Fife
}

(Accepted for publication 5 December 1968)

SUMMARY

Membranes from Sarcina flava were solubilized by using I \%(v/v) Lubrol L and a water-soluble detergent-rich carotenoid glycoprotein complex isolated and purified. Homogeneity of the complex was indicated on the ultracentrifuge but molecular weight determinations made on a membrane osmometer indicated that the molecular weight values obtained in the presence of detergent may depend on the presence or absence of salts.

\section{INTRODUCTION}

The use of synthetic detergents for the solubilization of protein complexes or of membranes is widespread (Smith, 194I; Salton \& Netschey, I965; Salton, 1967; Bailey, 1968). Since it is sometimes impossible to remove detergent from solubilized material, molecular weights have been determined in the presence of detergent (Wolken \& Schwertz, 1956). The carotenoids of Sarcina flava are localized in the membrane (Strang, I968) and it is likely that the dihydroxy $\mathrm{C}_{50}$ carotenoid (Thirkell, Strang \& Chapman, 1967) becomes an integral part of the structure of the membrane fraction. This work was to attempt to isolate and purify the complex so formed and to determine its molecular weight.

\section{METHODS}

Growth and harvesting of bacteria; preparation of carotenoid-glycoprotein. Sarcina flava (NCTC 7503) was grown in nutrient broth (Oxoid Ltd.) at $34^{\circ}$ and harvested after 3 days. The membrane fraction was isolated by the method of Salton \& Freer (I965) and solubilized by repeated extractions with I \% Lubrol L (I.C.I. Ltd.) in

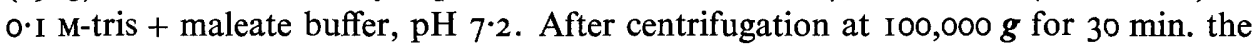
clear yellow supernatant fluid was exhaustively dialysed against tap water followed by distilled water. The carotenoid-glycoprotein was purified by repeated precipitation with $\left(\mathrm{NH}_{4}\right)_{2} \mathrm{SO}_{4}$ followed by dialysis.

Ultracentrifuge for homogeneity. Solutions in distilled water or $0 \cdot \mathrm{I} \mathrm{M}-\mathrm{KCl}$ were exhaustively dialysed against their respective solvents for more than $48 \mathrm{hr}$. Concentrations were determined by dry weight and ash, and by refractometry.

Molecular weight determinations. Osmometry was used on both solutions in a high-speed Hewlett-Packard membrane osmometer equipped with B I9 membranes (Schliecher \& Schüll). In each case, reduced osmotic pressures were plotted against concentration. 


\section{RESULTS}

The complex contained carotenoid (indicated by spectrum and by reaction with $\mathrm{SbCl}_{3}$ (Morton, 1942), sugar(s) (by the method of Whistler \& Wolfrom, 1962) and a peptide (amino acid analysis). Sedimentation in distilled water or $0 . \mathrm{I} \mathbf{M}-\mathrm{KCl}$ after I $80 \mathrm{~min}$. at a nominal speed of $59,780 \mathrm{rev}$./min. gave symmetrical schlieren patterns indicating a single compound characterized by a $S_{20}^{0}$ value of $1 \cdot 49 \times 10^{-13} \mathrm{sec}$.

Reduced osmotic pressure measurements recorded in the presence or absence of $\mathrm{KCl}$ were plotted against concentration (Fig. I). Correction for non-ideality of solution was carried out by extrapolation to zero concentration and the results fitted into the general formula:

$$
\bar{M} n=\frac{R T}{(\pi / c)_{c \rightarrow 0}}
$$

where $R T$ was corrected for the density of the solvents. From the figure, an $\bar{M} n$ value of $2.28 \times 10^{4}$ was obtained for the preparation in distilled water, and $6.20 \times 10^{4}$ for the preparation in $0.1 \mathrm{M}-\mathrm{KCl}$. The shapes of the curves are strongly suggestive of association of macromolecules.

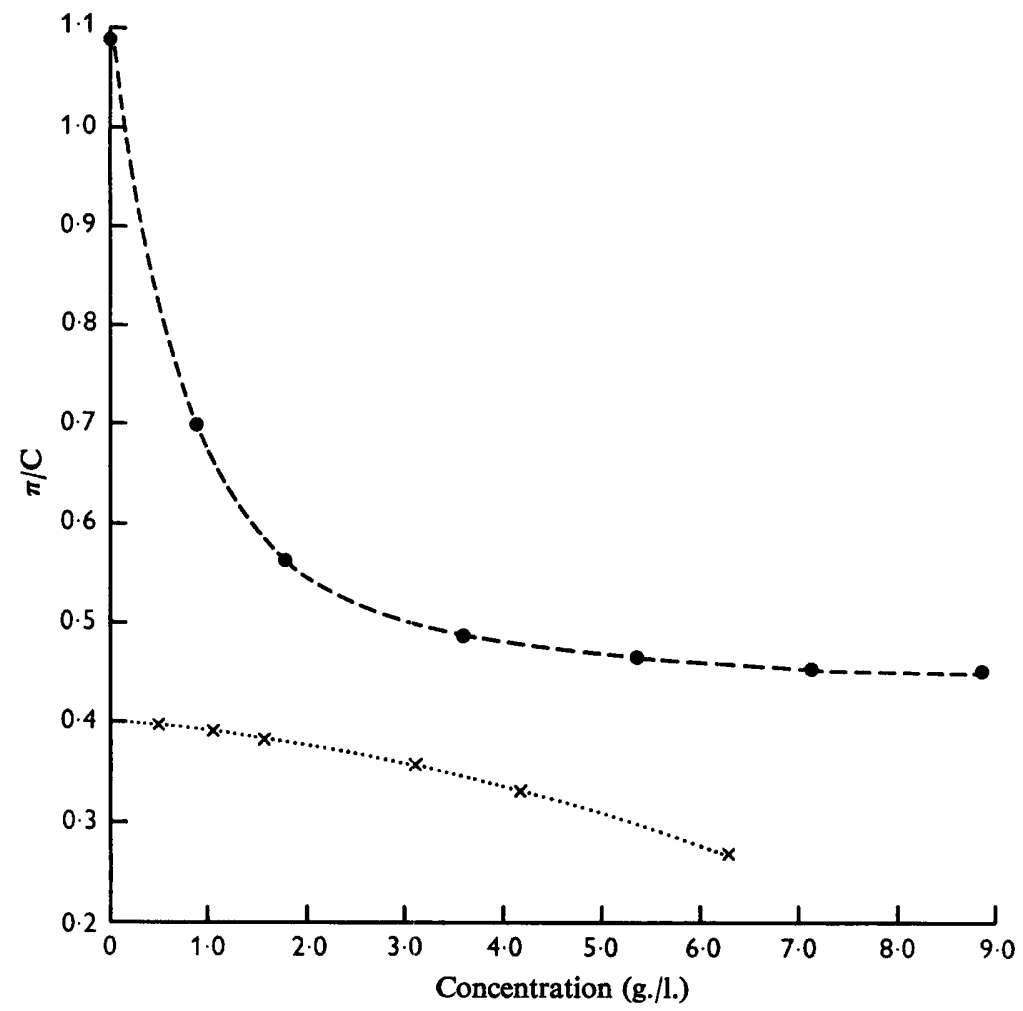

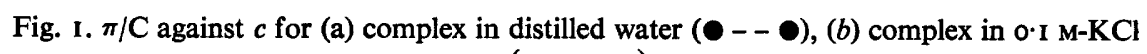
$(x-\ldots)$. 


\section{DISCUSSION}

Addition of salt to a detergent-rich solution appears to bring about association of macromolecules, increasing micelle size to a point where the solubility properties of the solution tend towards those of the detergent itself. This view is supported by the discrepancy of $\bar{M} n$ values recorded on the osmometer. Molecular weights determined in the presence of detergent may also depend on the technique used and the concentration of solution. Any molecular weight values determined in the presence of high concentrations of detergent may be open to doubt.

We thank I.C.I. Ltd. for a gift of Lubrol L. One of us (D.T.) is supported by a grant from the Science Research Council.

\section{REFERENCES}

BaIley, J. L. (1968). Characterization of pigment-protein complexes related to systems I and II. Int. Congr. Photosyn. Res., Freudenstadt.

Morton, R. A. (1942). Absorption spectra Applied to Vitamins and Hormones. London: A. Hilgar.

Salton, M. R. J. (1967). Struture and composition of bacterial membranes. Protides biol. Fluids r5, 279.

Salton, M. R. J. \& Freer, J. H. (1965). Composition of the membranes isolated from several Grampositive bacteria. Biochim. biophys. Acta ro7, 531 .

Salton, M. R. J. \& Netschey, A. (1965). Physical chemistry of isolated membranes. Biochim. biophys. Acta ro7, 539.

SMITh, E. L. (194I). The chlorophyll-protein compound of the green leaf. J. gen. Physiol. $24,565$.

Strang, R. H. C. (1968). Some investigations into the Sarcina bacteria. Ph.D. Thesis, St Andrews University.

Thirkell, D., Strang, R. H. C. \& Chapman, J. R. (1967). The pigments of S. flava: a new series of $\mathrm{C}_{50}$ carotenoids. J. gen. Microbiol. 49, 157.

Wolken, J. J. \& Schwertz, F. A. (1956). Molecular weight of algal chloroplastin. Nature, Lond. 177, 136.

Whistler, R. L. \& Wolfrom, M. L. (1962). Methods in Carbohydrate Chemistry, vol. I, p. 388, New York and London: Academic Press. 